Relations industrielles

Industrial Relations

\title{
Wage Policy
}

\section{Jacques St-Laurent, Marc-Adélard Tremblay et Yves Dubé}

Volume 24, numéro 1, 1969

URI : https://id.erudit.org/iderudit/027988ar

DOI : https://doi.org/10.7202/027988ar

Aller au sommaire du numéro

\section{Éditeur(s)}

Département des relations industrielles de l'Université Laval

\section{ISSN}

0034-379X (imprimé)

1703-8138 (numérique)

Découvrir la revue

Citer cet article

St-Laurent, J., Tremblay, M.-A. \& Dubé, Y. (1969). Wage Policy. Relations

industrielles / Industrial Relations, 24(1), 82-86. https://doi.org/10.7202/027988ar

Tous droits réservés @ Département des relations industrielles de l'Université Laval, 1969
Ce document est protégé par la loi sur le droit d'auteur. L’utilisation des services d'Érudit (y compris la reproduction) est assujettie à sa politique d'utilisation que vous pouvez consulter en ligne.

https://apropos.erudit.org/fr/usagers/politique-dutilisation/ 
ment résulteront en des augmentations de coûts de production et à la fin des prix. La main-d'oeuvre doit, en particulier, être constamment réentraînée et incitée à se déplacer des régions où des industries de productivité plus basse à celles qui le sont plus.

Ceci implique qu'une politique salariale au Canada n'est pas justifiée. Elle pourrait même être nuisible dans la mesure où elle introduirait des rigidités additionnelles. Mais la politique de laisser-faire à ce point de vue peut quand même s'accommoder de certains blocages de salaires et de prix dans des secteurs industriels ou des zones géographiques que l'on veut reconvertir. Mais même dans ces secteurs le blocage ne pourra être que temporaire.

Il y a toujours le danger que les parties en présence soient trop prudentes et interviennent trop peu et trop tard. C'est le cas des gouvernements et des unions ouvrières. Il se peut que la situation que nous avons connue ait pu être prévenue par une action plus éclairée des patrons, des unions et du gouvernement. Mais dans l'ensemble, étant donné les objectifs poursuivis, elle était inévitable.

\title{
Wage Policy
}

\author{
Jacques St-Laurent \\ Marc-Adélard Tremblay \\ Yves Dubé
}

\section{NOTION, OBJECTIVES, POSSIBILITIES}

There are many different definitions for the term \& wage policy s. In a broader sense it could be defined as being all policy influencing the development of wages. This description is much too broad for it includes all factors influencing the demand or supply of labor.

One could also speak about the wage policy of the employers (governments or others) and the wage policy of the union as an employer and as a representative organization of the workers.

Strictly speaking one might say that it regards the specific criteria or the e landmarks > established by a government in order to lead all employers or employees to be submitted to it. These are measures concerning the economy as a whole. 


\section{THE GOALS}

The formulation of a wage policy first requires the definition of the desired goal. This is not an easy task. Generally speaking this formulation necessitates predictions either on the future standing of the economy either on the evolution of productivity.

In the former case those annual predictions must be revised considering the changes of the economic reality on which the State has no control. A larger control of those changes would imply a more advanced planning susceptible of being refused by the population. Without such a control predictions lack of precision and the goals of the wage policy could not be achieved.

In the latter case the choice of the length of statistic series and of the method to be used will surely affect the value of productivity and many discussions will arise depending upon the personnal interests of each and everyone concerned.

Even if these difficulties are settled and a rate of increase in wages established there still is the problem of modifying this rate in order to consider the evolution of the labor market. In fact this evolution is not identical in all occupations and all regions of a country. This is the main difficulty of the application of a wage policy.

\section{The MeANS}

Once general or particular standards are established, there must be means forcing the employers and employees to stick to them. The simplest way is persuasion. It is a weak instrument for the conditions of its efficiency are rarely realized.

More drastic measures must then be found. The intervention of the legislator is an unpopular way except in circumstances where the public interest explicitly asks for it. Those circumstances usually are quite unpleasant : the reorganization of an economy following a war or serious problems in the balance of payments.

The presence of a legislation is not necessarily efficient. One usually finds tricky ways to avoid it. In addition to this a wage policy is not consistent with the requirements of an international or interprovincial labor market. There is a risk of lack or excess of manpower in the short period.

\section{THE FACTS}

Surveys on wage policy held in different western countries lead to the conclusion that there has been a lot more talking than concrete action taken regarding wage policy. In countries where it has efficiently been used, its success has directly been function of the steadyness of existence of the unhappy circumstances that gave birth to it. On our side of the world the «landmarks » set by the American president have been quite criticized. It has been said that they should be used before the full employment in firms or unions more or less free to establish prices and 
salaries by calling upon their sense of responsabilities. Those «landmarks 》 have also been treated of undesirable because they misplaced the real causes of the malaise and that they led to serious distortions in the relative prices.

\section{CONCLUSION}

It is therefore very difficult to explain the popularity surrounding the discussions on wage policy. Do they only aim at increasing the status and the political power of those speaking about it?

\section{SOCIO-ECONOMIC CONSEQUENCES OF CONSUMING PATTERNS}

The survey conducted by the author with Professor Gérald Fortin on the economic behaviour of wage-earning families of Quebec (1) showed that the French Canadian family of today has acquired the new needs of modern, industrial civilization, which are better home equipment and appliances; modern furniture : greater security against risks of all kinds; automobile and commercialized leisure activities. These «modern» needs are universal and increase with the economic betterment of the family and its possibilities on the credit market. In this respect, urban and rural families are alike and there are no differences between white collar families and families of unskilled laborers. Subjectively speaking they all strive towards achieving what is considered to be the «standard package » of: goods and services.

These observations stress the anachronic character of the concept of « the minimum level of living 》 and bring forth the new societal objective of \& optimal well-being $\gg$ of the individual and family. There is also the brutal reality of the economically weak people who are deprived as yet of the most essential goods and services of technological society. It is difficult to establish criteria by which we could arrive at a clear-cut conception of what is « optimal well-being ». It is being suggested that we should initiate large-scale programs to educate better the consumer on its real financial possibilities and exert more strict controls on commercial publicity.

We have experienced in the past that it is hard in a society such as ours to reach full employment. Therefore we should strive towards establishing a better overall program of social security that would take into account these emerging patterns associated with modern life so that we could move towards programs that are constructive and preventive. It is not only a question of protecting individuals against certain risks but it is also a question of equiping them with the skills and the creative imagination that will allow them to reduce the gap between technological and socio-economic progress.

(1) Tremblay, M. A., and Fortin, G., Les comportements économiques de la famille. salariée du Québec, P.U.L. Québec, 1964, 405 pages. 


\section{WAGE POLICY AND THE ECONOMIC CYCLES}

It is a widespread belief that wage policies are a must and that they have to be defined according to the economic cycles. I do not share such a thesis. At the contrary, I believe neither in wage policy nor in the inevitability of economic cycles and nor in the possibility for a given wage policy to influence the economic cycle. In the demonstration of my thesis I naturally exclude the policy of the government towards its own employees.

From 1962 to 1964 wage increases in percentage have been smaller than the increases of productivity and profits. However 1965 is a boom year for wages. From 1965 to 1966 one can see that wage increase in percentage was from 10 to $11.2 \%$. Workers wanted more and employers did not resist very much to their demand. Profit decreases are accompanied by a decrease in the rate of change of productivity. By 1967, the increase rate of productivity became zero. This decrease in profits can be explained in part by the large increase in wages and by the decrease in the rate of change of productivity.

From this very brief analysis, it seems that we were faced with a series of complex phenomena: an increase in the effective demand led to an increase in productivity which finally led to an increase in wages. We then saw all sort of constraints blocking this increase in productivity. The logical result was an increase in costs, and unemployment.

Before concluding that a wage policy is needed for Canada we must ask ourselves wether this evolution was normal or not.

\section{Causes of the Rise in Wages}

According to Perry there are five causes or factors explaining the rise in wages:

a) the corporations' rate of profit in the preceeding period;

b) the rate of unemployment in the preceeding period;

c) the level of prices;

d) the direction of the change in profits;

e) the direction of the change in unemployment.

Because of the close relationship between those factors, it seems preferable to adopt policies regarding rather than wages only.

\section{Increase in Wages and Improvement of Overall Demand Productivity}

In the last two year context of considerable wage increase, of price increase and of stability in productivity, a drastic solution to inflation must be brought forward. There is only one way of stabilizing price increase in insuring full employment and wage increase and that is in trying to increase the total productivity of the economy. 
It seems that the increase in wages and prices that we have known in the last two years is a cyclinal phenomena and that this situation has already begun to change.

\section{The Public Services}

The right to negotiation and to strike in the public services leads to particular difficulties :

a) wage negociations cannot be based on profits;

b) costs are met by the citizens' tax payments;

c) the public services can set wage patterns for the whole economy.

\section{The Wage Policy}

I define wage policy as a continued effort of the government to control the evolution in wages in the different parts of the economy.

The solution to this complex problem seems to be, in my opinion, in the search for a more regular progression in the factors we have examined. In my mind this progression depends on monetary and fiscal policies.

\section{The Proposed Solutions}

An income policy

The Canadian Economic Council in against such a solution. Their arguments are convincing.

\section{The Guidelines}

Those guidelines have some value in the long period for the whole economy but are useless for negotiation in a particular sector at a given moment in time in a given region.

\section{Pay Research Bureau}

I do not see how such an institution could deal with a problem as complex as the one we are examining.

\section{CONCLUSION}

1.-It would be easier to insure more regular increases in wages if we could achieve and maintain full employment.

2.-A full employment policy must be accompanied by a policy aiming at increasing the productivity of the firms and of the economy as a whole.

All this leads to the conclusion that a wage policy in Canada would not be justified at the present time. At the contrary the more it would bring additional rigidities the more it would be harmful. 